\title{
PROTOTYPE SOLAR POWER PLANT IN LABORATORY ELECTRICAL ENERGY CONVERSION
}

\author{
Titus Tandi Seno ${ }^{1}$, Charnia Iradat Rapa ${ }^{2}$ \\ ${ }^{1}$ Departement of Electrical Engineering, Paulus Christian University Of Indonesia Makassar, Indonesia \\ ${ }^{2}$ Departement of Electrical Engineering Paulus Christian University Of Indonesia' Makassar, Indonesia
}

\begin{abstract}
Continuity and availability of electrical energy have to maintained, the government appealed for saving electrical energy. The lack of electrical energy conversion research centers in universities lead to knowledge conversion of electrical energy to the campus community is still limited.These problems will be conducted research design and test of Solar Power Plant in Electrical Energy Research Center UKI Paul Makassar. Solar energy is converted into electrical energy obtained through Solar Power Slant System (photovoltaic).The purpose of this research is to design and analyze the amount of energy produced by Solar Power Plant to study the electrical energy at laboratoty of the electrical energy conversion UKI Paulus Makassar. This study used a method of literature study, system design, and analysis. Characteristics of the solar panels used capacity of 9 units $x 50=450$ $W p$ are connected in parallel, $V_{\max }=25.5$ Volts, $I_{\text {out }}=14 \mathrm{~A}$, the operating time of 6 hours each day. Capacity of the accumulators $2 \times 12$ Volt units $=24$ Volt, $65 \mathrm{Ah}$. Current capacity of the battery charge regulator (BCR) $40 \mathrm{~A}$. Capacity of $10 \mathrm{~kW}$ power inverter Testing of solar systems to use solar insolation data is lowest at 3:51 days/ hours.
\end{abstract}

Key Words: Solar Power Plant (SPP), Solar Panels, Solar Energy

\section{INTRODUCTION}

The solar cell panel is a device that can convert sunlight into electrical energy. The use of solar cell panels as power generation has great potential due to the located in Indonesia of the tropical world, where the sun shines all the time, then it is appropriate if the sunlight used as a source of electrical energy providers, known as generator of Solar Power Plant (SPP). In the planning and testing of solar system, the important factor is how to determine types of components required in accordance with needed of the load, the location where the system will be placed, environmental conditions and other restrictions that need to be considered. To ensure that no failure occurs in the system or reduce the maximum possible system failure. So, need to know also if the problems of what happens in the planning and designing of solar system. Except of that in the planning and designing of a solar system, ofcourse need a steps to must be done for achieve maximum results. Therefore, the discussion of the planning and testing of solar systems, among others, will be presented matters relating to the capacity of the main components of solar systems. The main components of solar systems consist of solar panels; battery; Battery Control Relay (BCR); Inverters and components including wiring, connectors, switches, fuse, grounding and protection circuit.

\section{LITERATURE}

\subsection{Solar Energy}

Solar energy is very attractive because of non-polluting, can not be discharged, and free. Two main ugliness of this solar energy is very smooth and constant. Low The current of solar energy resulting forced to use a broad collector system and large a surface to collect and concentrate the energy.
Solar energy can be converted directly into other energy forms. Solar thermal energy is one of the potential energy to be managed and developed further as a backup source of energy, especially for the country - a country located at the equator, including in Indonesia, where the sun shines all year round. There are several ways that solar thermal energy utilization, among others, heating, lighting, stove sun, drying agricultural products, dirty water distillation, water heating, electricity generation.

\section{THE EFFECT OF EMISSION INTENSITY OF SUN}

The intensity of sunspots is an important determinant of performance solar systems. Influence the emission intensity of the sun have a considerable influence on the current (I) and voltage $(\mathrm{V})$. Emission unit is $\mathrm{w} / \mathrm{m} 2$. Solar cell panel will generate electricity in accordance with the accepted level of sunspots. This emission level different from one place to another, influenced by the location of equator, altitude and sea level, cloud, pollution levels, humidity and temperature.

\section{THE WORK PRINCIPLE OF SOLAR SYSTEM}

In the day the solar cell panel receives sunlight which converted into electricity through a process fotovolteik. The electricity generated by the panel that can be directly channel to load or stored in batteries before being to distributed to the load. At night, in which the solar cell panels do not produce electricity, the load is fully supplied by the battery. Similarly, on cloudy's day, where the solar cell panels produce electricity is lower when the sun is shining. 


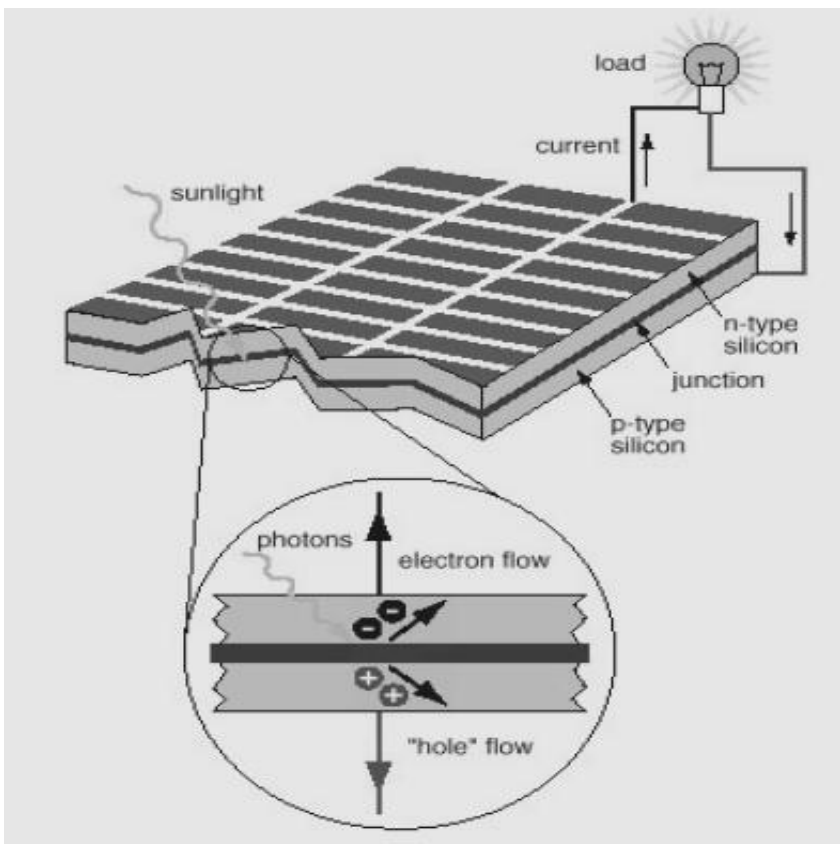

Fig-1: The conversion of sunlight into electricity[7]

Energy contained sunlight in the form of photons. When these photons received solar cell surface, electrons will be excitation and cause the flow of electricity. Solar cell can be excitation because it made by semiconductor material, which contains the element silicon. Silicon is composed of two types of layers are n-type (negative) layer and p-type (positive) layer. The solar cell is easily broken and rust if exposed to water. Because of these cells are made in the form of a certain size panels where coated with plastic or clear glass that is watertight. This panel is known as the solar cell panel. We can design a series of panels, solar cells, in series or in parallel, in order to obtain the output voltage and current desired. To obtain an alternating current (AC) required an additional tool called an inverter.

\section{TECHNICAL OF CALCULATION:}

Capacity Calculation Panel Solar Cells:

The power generated by the solar cell panels maximum measured by the amount of Wattpeak (Wp), and converted to watthour (Wh) depending on the intensity of sunlight on the surface of the panel. Adjustment factor is 1,1 . In the order of that solar system installation can fill the needs of the load at any time, so, used the data lowest solar insolation. Furthermore, the power output by the solar panels are [1] - [2] - [3] - [5]. Furthermore, the power output by the solar panels are:

Pmax $=\frac{E T}{\text { Sun insolasi }} \times$ adjustment factor

Battery Capacity of Calculation Unit of energy (Wh) is converted to appropriate Ah battery capacity:

$$
A h=\frac{E T}{V S}
$$

To ensure that the system can operate properly fit to needs of the load, need to account weather conditions without sunlight (day otononi) are generally calculated for 5 days. Deep of discharge (DOD) on the battery to $80 \%,[1]-[2]-$ [3], the battery capacity required:

$$
C b=\frac{E b \times d}{V \times K b}
$$

C. Battery Control Relay Of Calculation (Bcr):

The load on solar system taking energy from the BCR. capacity of current pouring in BCR can be determined by knowing the maximum power installed so, the capacity of the current flowing in the BCR:

$$
l \max =\frac{P \max }{V s}
$$

\section{d. Inverter:}

Specifications inverter must be in accordance with the Battery Control Relay (BCR) are using. Current capacity of the inverter is using must be greater than the capacity of the BCR.

\section{METHODS OF RESEARCH}

\subsection{Location of Research:}

Energy Conversion Laboratory Departement of Electrical Engineering, Paulus Christian University Of Indonesia.

\subsection{Study Library:}

Study of literature related to Solar Power System.

\subsection{Design and Installation:}

Design and installation of solar systems subsequently conducted surveys, direct observation and measurement of solar radiation reaching the solar cell panels around the site is a place to conduct research in the campus of UKI Paulus Makassar where the position of the solar cell modules in pairs horizontally or directed to the position of the sun. The activity program is a case of study, so that the program material is generally in the form of field data strongly support the design of solar systems.

\section{Materials and tools include:}

- Solar cell panel

- Batteries

- Battery Control Relay (BCR)

- Inverter

- Multimeter

- Ammeter

- Voltmeter

- Cables, connectors, switches, fuse, grounding and protectioncircuit. 


\section{RESULTS AND DISCUSSION}

\subsection{Design and Calculation}

\subsubsection{Picture of The Design Prototype Of Solar}

\section{Systems}

Pictures circuit design prototype of solar systems for testing the performance of solar cells as shown below:

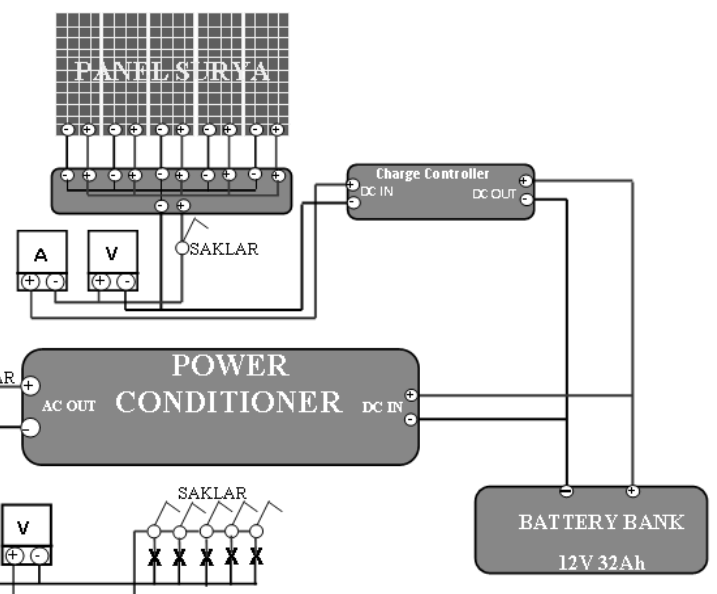

Figure-2. The circuit design of a prototype solar

\subsubsection{The System Capacity SPP of Calculation}

The initial step in planning and designing of solar systems are determination of the total daily load to be supplied by solar electric power, total daily load is the amount of energy required by the electric load to be fed everyday. The total load is the amount of energy required electrical load everyday. Load attached, installed power, longer used the load, as well as the energy needs to prototype everyday in Table 1 below.

Table.1 data type will load electrical power supplied

\begin{tabular}{|c|c|c|c|c|c|c|}
\hline No & $\begin{array}{l}\text { Kind of } \\
\text { load }\end{array}$ & $\begin{array}{l}\text { powe } \\
\mathbf{r} \\
(\mathbf{w}) \\
\end{array}$ & $\begin{array}{l}\text { sum } \\
(\mathbf{n})\end{array}$ & $\begin{array}{l}\text { Power } \\
\text { total } \\
P_{t}=P \times n\end{array}$ & $\begin{array}{l}\mathbf{T}_{\text {oprs }} \\
\text { (hours) }\end{array}$ & $\begin{array}{l}\text { Wh } \\
=\left(P_{t} \times t\right)\end{array}$ \\
\hline 1 & $\begin{array}{l}\text { Lamp: } \\
\text { LED's } \\
\text { Neon }\end{array}$ & $\begin{array}{l}14 \\
10\end{array}$ & $\begin{array}{l}3 \\
6\end{array}$ & $\begin{array}{l}42 \\
60\end{array}$ & $\begin{array}{l}4 \\
4\end{array}$ & $\begin{array}{l}168 \\
360\end{array}$ \\
\hline 2 & $\begin{array}{l}\text { Colour } \\
14 " \mathrm{TV}\end{array}$ & 60 & 1 & 60 & 6 & 240 \\
\hline 3 & Laptop & 65 & 1 & 65 & 4 & 260 \\
\hline 4 & $\begin{array}{l}\text { Tape } \\
\text { Recorder }\end{array}$ & 30 & 1 & 30 & 4 & 120 \\
\hline 5 & Fan & 52 & 1 & 52 & 2 & 104 \\
\hline \multicolumn{6}{|c|}{ TOTAL Wh } & 1252 \\
\hline
\end{tabular}

Data total daily load is the basis for calculating the capacity of main components of solar panel systems are Solar Cells, Batteries, BCR, and Inverter. Results Calculation capacity solar system's main components in Table 2 below.
Table-2: Capacity of Calculation Main Components of solar system

\begin{tabular}{|c|c|c|c|}
\hline $\begin{array}{l}\text { System } \\
\text { components }\end{array}$ & \multicolumn{2}{|c|}{ Comparison } & Calculation \\
\hline \multirow{3}{*}{$\begin{array}{l}\text { The capacity } \\
\text { of solar cell } \\
\text { panel }\end{array}$} & $\begin{array}{l}\text { System } \\
\text { load } \\
\text { supply } \\
\text { of SPP }\end{array}$ & $\mathrm{E}_{\mathrm{A}}=100 \% \times \mathrm{E}_{\mathrm{B}}$ & $1252 \mathrm{Wh}$ \\
\hline & $\begin{array}{l}\text { Losses } \\
\text { System } \\
(15 \%) \\
\end{array}$ & $\underset{\text { system }}{\mathrm{E}_{\mathrm{T}}}=\mathrm{E}_{\mathrm{A}}+\mathrm{P}_{\text {loss }}$ & $1440 \mathrm{Wh}$ \\
\hline & $\begin{array}{l}\text { Psolar } \\
\text { panels }\end{array}$ & $\begin{array}{l}\mathrm{P}_{\max }= \\
\mathrm{E}_{\mathrm{T}} /(\text { sun Insolation ) } \\
\mathrm{x} 1.1\end{array}$ & 451.22 Watt \\
\hline \multirow{2}{*}{$\begin{array}{l}\text { Capacity of } \\
\text { battery }\end{array}$} & $\mathrm{Ah}$ & $\mathrm{Ah}=\mathrm{E}_{\mathrm{T}} / \mathrm{Vs}$ & $119.98 \mathrm{Ah}$ \\
\hline & $\begin{array}{l}\text { DOD } \\
(80 \%) \\
\text { Ch } \\
\end{array}$ & $\mathrm{Ch}=(\mathrm{Ah} * 1) / \mathrm{DOD}$ & $149.98 \mathrm{Ah}$ \\
\hline $\begin{array}{l}\text { BCR } \\
\text { capacity }\end{array}$ & $\mathrm{BCR}$ & $\mathrm{I}_{\max }=\mathrm{P}_{\max } / \mathrm{Vs}$ & 37.60 Amp \\
\hline $\begin{array}{l}\text { Inverter } \\
\text { capacity }\end{array}$ & $\begin{array}{l}\text { INVER } \\
\text { TER }\end{array}$ & $\begin{array}{l}\mathrm{P}_{\max } \\
=\mathrm{E}_{\mathrm{T}} /(\text { sun insolation }) \\
\mathrm{x} 1.1 \\
\text { or } \\
\mathrm{I}_{\max }=\mathrm{P}_{\operatorname{mak}} \times V_{\mathrm{s}}\end{array}$ & $\begin{array}{l}\text { 451.22 Watt } \\
37.60 \mathrm{Amp}\end{array}$ \\
\hline
\end{tabular}

Table 2 the results of the calculation of the capacity of solar cell panels can distribute the load of 451.22 Watt, this value associated with low solar insolation data is the city of Makassar is $3.51 \mathrm{~h} / \mathrm{h}$, is also affected by the adjustment factor is 1.1 in most solar installations. The battery capacity of $149.98 \mathrm{Ah}$ calculation results. This result was influenced by the total energy use (ET) and operating voltage (Vs), the autonomy of 1 day and 80\% DOD. The capacity of 37.60 Amp BCR calculation results are affected by the solar module power (Pmax) and operating voltage (Vs). The capacity of the inverter must be equal or greater capacity or capacity Pmax solar panels BCR. Examples of capacity ratio of $50 \mathrm{Wp}$ solar cell panels are available with the results of calculations based on the data of the open circuit voltage (Voc), short circuit current (ISC), the maximum power current $(\mathrm{Vmp})$, and the maximum power current $\left(\mathrm{I}_{\mathrm{mp}}\right)$, in Table 3 below:

Table-3: Comparison of capacity Panels of Solar Cells Counted Capacity and Available

\begin{tabular}{|l|l|l|l|}
\hline & $\begin{array}{l}\text { Available } \\
\text { Capacity }\end{array}$ & Comparison & Calculation \\
\hline $\begin{array}{l}\text { The } \\
\text { Power } \\
\text { Of } \\
\text { Solar } \\
\text { Panel } \\
\text { System } \\
\text { s }\end{array}$ & $50 \mathrm{Wp}$ & Pmax=Voc* Isc*FF & $50.02 \mathrm{Wp}$ \\
\hline $\begin{array}{l}\text { Fill } \\
\text { Factor } \\
\text { (FF) }\end{array}$ & & $\begin{array}{l}\text { FF=(Vmp*Imp)/(Voc } \\
\text { FIsC) }\end{array}$ & 0.69 \\
\hline
\end{tabular}


Fill factor is a parameter that determines the input power (Pimput) of the solar cell panel which affects the maximum power (Pmax) solar cell panels $50.02 \mathrm{Wp}$ calculation capacity and the available capacity of $50 \mathrm{Wp}$. Capacity calculation results with the available capacity of the difference is so small to use solar cell panel $50 \mathrm{Wp}$. Comparison between the main components of solar capacity by calculation and available in Table 4 below.

Table-4: Comparison of main Component Capacity of solar sistem are Available and implicatly

\begin{tabular}{|c|c|c|c|}
\hline $\begin{array}{l}\mathbf{N} \\
\mathbf{0}\end{array}$ & $\begin{array}{l}\text { The Main } \\
\text { Compone } \\
\text { nt Of Plts } \\
\text { System }\end{array}$ & $\begin{array}{l}\text { Capacity } \\
\text { Based On } \\
\text { Calculation }\end{array}$ & $\begin{array}{l}\text { Available } \\
\text { Capacity }\end{array}$ \\
\hline 1 & $\begin{array}{l}\text { Solar Cell } \\
\text { Panels }\end{array}$ & $451.22 \mathrm{Wp}$ & $\begin{array}{l}50 \mathrm{Wp} \times 9=450 \\
\mathrm{Wp}\end{array}$ \\
\hline 2 & BCR & 37.60 Ampere & 40 Ampere \\
\hline 3 & Battery & $149.98 \mathrm{Ah}$ & $150 \mathrm{Ah}$ \\
\hline 4 & Inverter & $451.22 \mathrm{AW}$ & 500 Watt \\
\hline
\end{tabular}

Table 4 The comparison of capacity is available to capacity calculation results of solar system's main components, name are solar module panels, BCR, battery and inverter qualify the data type of load for the prototype power supply are met.

\section{B. Data Prototype}

Indicators in achievement of objectives are used to declare the success of research with engineering specifications prototype solar systems based on calculations and available, in Table 5 below.

Table-5: Activity Indicators

\begin{tabular}{|l|l|l|}
\hline No & Indicators Results & Unit \\
\hline 1. & Capacity of solar panel & $9 \times 50 \mathrm{Wp}$ \\
\hline 2. & Capacity of battery & $2 \times 80 \mathrm{Ah}$ \\
\cline { 2 - 3 } & Battery types & VRLA/* \\
\cline { 2 - 3 } & DC Power Output & 12 Volt \\
\hline 3. & Strains Output AC & 220 Volt \\
\hline 4. & $\begin{array}{l}\text { Total power Output-Maximum (the } \\
\text { daily resource) }\end{array}$ & 450 Watt \\
\hline 5. & Inverter power & $10 \mathrm{~kW}$ \\
\hline 6. & Frequency & $50 \mathrm{~Hz}$ \\
\hline 7. & NEON's lamp & $14 \mathrm{Watt}$ \\
\hline 8. & LED's Lamp & $10 \mathrm{Watt}$ \\
\hline 9. & warnah 14 “s TV & $60 \mathrm{Wa} \mathrm{tt}$ \\
\hline 10. & Laptop & $65 \mathrm{Watt}$ \\
\hline 11. & Tape recorder & $30 \mathrm{Watt}$ \\
\hline 11. & Fan & $52 \mathrm{Watt}$ \\
\hline 12. & $\begin{array}{l}\text { Operating time of solar panels } \\
\text { Average /day }\end{array}$ & $\begin{array}{l}6 \mathrm{hours} \\
\text { hours }\end{array}$ \\
\hline 13. & Long operation load average/day 6 \\
& &
\end{tabular}

\section{Testing}

At the time of data collection voltages, currents and solar power, the state of the sunny weather conditions, wind speed of $2.1 \mathrm{~m} / \mathrm{s}, 60 \%$ humidity, temperature is $320 \mathrm{C}$. The results of current and voltage measurements, and the visible solar power lighting effect of the change in voltage, at 1:00 PM PST, the maximum visible light intensity of the output voltage of 20 volt panel as shown in the following graph:

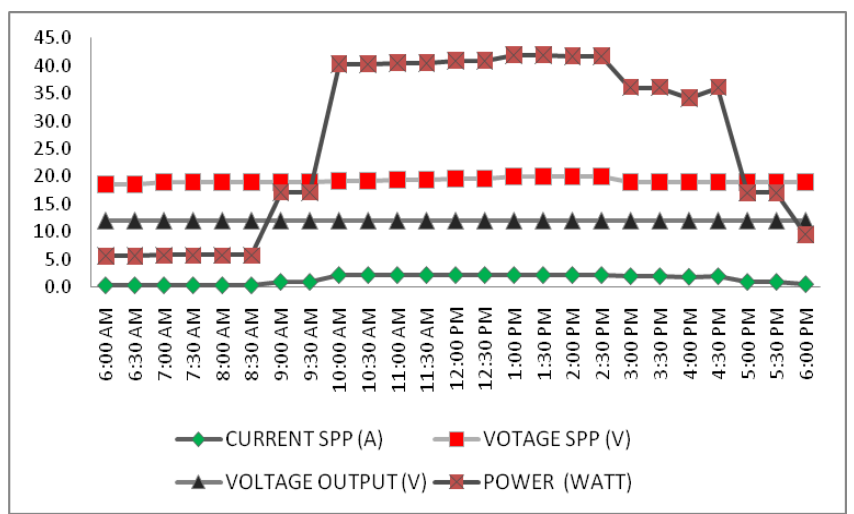

Graph- 2: The results of the measurement of current, voltage and solar power pant

From the above chart shows the voltage of the solar cell panel fluctuated depending on the intensity of sunlight and time. This is evidenced when at 08:00 AM solar cell panel voltage is 19 volts but at 10:00 AM to 12.00 AM rise until $19.2 \mathrm{~s} / \mathrm{d} 19.5$ Volt to the top at 1:00 pm PM, but not promising at 2:00 PM reduction to 19.9 volts to 18.9 volts lowest point at 5:00PM.

\section{CONCLUSIONS}

[1]. Design of prototype's solar systems designed for the conversion of electrical energy as a laboratory experiment module with power requirements $\mathrm{Wh}$ per day in 1252, the power of 450 Watt solar panel $50 \mathrm{Wp}$ panel takes about 9 pieces, 80 Ah battery as much as 2 pieces, BCR capacity of 40 Amperes and Inverter capacity $10 \mathrm{~kW} 1$ piece.

[2]. In the prototype testing and solar systems to the area of Makassar, the lowest solar insolation data used is $3.51 \mathrm{~h}$ / h.

[3]. The result of solar cell panels energy every day is influenced by weather conditions, wind speed, humidity, temperature and load conditions.

\section{REFERENCES}

[1]. Hankins, Mark. Small Solar Electric System for Africa. Motif Creative Arts, Ltd. Kenya. 1991.

[2]. Liem Ek Biem, Isaac Kasim, Wahyu Wibowo. Hybrid's System Design Solar Power Generation with Jaa-nets PLN for home of city . JETri Journal, 8 (1): 37-56.2008.

[3]. Suriadi, Mahdi Shukri. Solar Power Planning (SPP) using the Integrated Software Engineering PVSYST on complex houses. Jurna's Elektrika, 9 (2): 77-80.2010.

[4]. Adjat Sudradjat. PLTS Technology Policy in 
Indonesia, P3 TKKE BPPT, Workshop Review Meeting manager of PLTS, MHP. Office of the State Minister of Cooperatives and Small and Medium Enterprises, 16-21 October 2001.

[5]. Solar Panel System 2011http // panelsurya.com

[6]. www.kamase.org.2007.

[7]. http://reslab.com.au/resfiles/pv/text.html.

\section{BIOGRAPHIES}

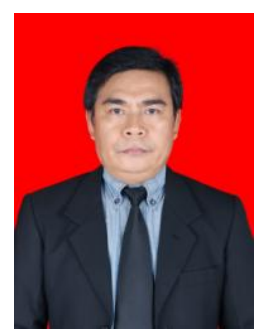

Titus Tandi Seno: Born in Tikunna Malenong, August 8, 1967. The author finished his education in Electrical Engineering of Electricity at Institute of Technology Bandung. Research in field is renewable energy Solar Power and a speaker at national Seminar Technology Industry in 2014.

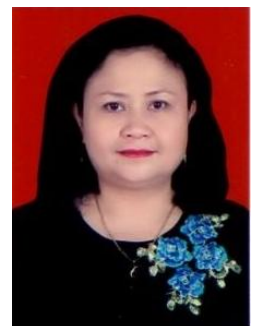

Charnia Irdat Rapa: Born in Rantepao, July 25, 1962. The Author finished his education of Elektrical Engineering in University of Hasanuddin Makassar. Research in the field is renewable energy and control has produced a scientific paper the results of research that modeling Control Flow Control Unit with PID controller. 